\title{
A Study on Energy Consumption in Snow Bound and Tribal Area of Himachal Pradesh, India
}

\author{
Tenzin Chhoerup $^{1}$, R K Aggarwal ${ }^{1, *}$, P K Mahajan ${ }^{2}$, S K Bhardwaj ${ }^{1}$, Subhash Sharma ${ }^{3}$ \\ ${ }^{1}$ Department of Environmental Science, Dr Y S Parmar University of Horticulture \& Forestry, Nauni, Solan (Himachal Pradesh), India \\ ${ }^{2}$ Department of Basic Sciences, Dr Y S Parmar University of Horticulture \& Forestry, Nauni, Solan (Himachal Pradesh), India \\ ${ }^{3}$ Department of Social Sciences, Dr Y S Parmar University of Horticulture \& Forestry, Nauni, Solan (Himachal Pradesh), India
}

Copyright (C) 2014 Horizon Research Publishing All rights reserved.

\begin{abstract}
A study was conducted in snow bound and tribal areas of Lahaul \& Spiti district to find out the energy consumption by the people in remote area bordering with Tibet. The space heating is a major requirement apart from cooking in the region. The fuel consumption in the study area indicated that the major fuels used for cooking were fuelwood $(55.46 \%)$, cowdung $(26.5 \%)$, kerosene $(9.05 \%)$, LPG $(8.64 \%)$ and electricity $(0.07 \%)$. The fuelwood consumption of about (48\%) by the households is in the range of $6-10 \mathrm{~kg} /$ day and that of the rest in the range $<5$ $\mathrm{kg} /$ day in the district during winters, whereas about $59 \%$ of households were consuming LPG in the range of 5-10 cylinders during summers. The annual fuelwood consumption of the district worked out to be 905.2 tonnes, all of which is being supplied by government on subsidized rates in limited quantity, the annual kerosene consumption of the district was 0.24 million liters and the annual LPG consumption of the district was 33.0 tonnes for cooking during summers.
\end{abstract}

Keywords Energy Consumption, Snow Bound Area, Tribal, Carbon Emission

\section{Introduction}

India is a country with more than 1.21 billion people and total land area of $3,287,263 \mathrm{~km}^{2}$ (Census, 2011). It faces a formidable challenge in providing adequate energy supplies to users at a reasonable cost. Per capita energy consumption in India is 3.7 times that of Japan, 1.55 times that of the United States, 1.47 times that of Asia and 1.5 times that of the world average. Thus, there is a huge scope for energy conservation in the country. India's demand for oil in 2015 is expected to be $41 \%$ higher than in 2007 and almost $150 \%$ higher in 2030 [1].

Around $75 \%$ and $10 \%$ of rural households depend on fuels like firewoods, and dungcake, respectively for cooking and about $44 \%$ do not have connections to electricity in their homes [2]. Rural households in India, in particular, are almost entirely depending upon traditional biomass for their basic cooking energy needs. This has adverse effects on their health and productivity, and also causes environmental degradation.

The country, though rich in coal and abundantly endowed with renewable energy in the form of solar, wind, hydro and bio-energy, has very small hydrocarbon reserves $(0.4 \%$ of the world's reserve). India, like many other developing countries, is a net importer of energy, more than 25 per cent of primary energy needs being met through imports mainly in the form of crude oil and natural gas [1].

The total energy utilized in rural India for the year 1971 was estimated as $10 \%(1.2 * 10 \mathrm{kcal} / \mathrm{year})$ of the total energy $(11.42 * 10 \mathrm{kcal} /$ year$)$ was derived from commercial sources, mainly contributed by kerosene, diesel, chemical fertilizers and electricity from hydro sources [3]. The remaining $90 \%$ is derived from traditional sources of energy, viz. human and animal labour, firewood, crop residues and animal wastes.

As per analysis of the energy scene in India conducted by [4] estimated on per capita energy consumption of the rural population, relying mainly on non-commercial energy sources, lies somewhere between 4.7 to $7 \mathrm{kWh} /$ day, which was much below the satisfactory minimum of $36 \mathrm{kWh} /$ day. In their opinion, the technologies appropriate for growth and development, biased in favour of rural India, may well require small scale decentralized energy systems, viz., biogas, solar and wind, with supplementary power coming, if necessary, from grid electricity.

Energy use patterns and resources assessment of the village, Islamnagar of Bhopal district of Madhya Pradesh was done systematically by [5], which showed that out of a total energy consumption of $2.46 \mathrm{GJ} / \mathrm{capita} /$ year, domestic activities consumed $2.08 \mathrm{GJ}$, of which cooking accounts for 2.03 and lighting $0.05 \mathrm{GJ}$. Sarma reported that the per capita domestic energy consumption in rural and urban areas of India was 0.35 tonne of coal equivalent per year [6]. The total energy consumption in India was about 196 million tonne of coal equivalent annually and $30 \%$ of domestic energy requirements were met from burning cow dung cakes, 
especially in rural areas, and 50\% from burning of fuel wood. In Uttar Pradesh, the per capita fuel wood consumption was worked out to be 1.98 per day. A detailed picture of energy consumption in a village ecosystem their study in Ungra village [7], Karnataka shows that biomass fuels account for $81 \%$ of the village energy budget, while commercial energy accounts for $11 \%$. The per capita consumption of energy was 13.1 GJ per year.

A study covering 136 households in Bharmaur block of district Chamba was conducted which revealed that the average annual consumption of fuel wood for cooking, heating and lighting purpose was 15.59 quintals per person and the large gap between the estimated demand and supply of fuel wood was $96 \%$ and was met by illicit felling. A survey was carried out in three panchayats in which it was estimated that the per capita annual fuel wood consumption of Himachal Pradesh at 8.15 quintals and was found that consumption was higher in mid hills (9.08 quintals) than the low hills (7.59 quintals) [9].

A pilot survey was carried out to identify the fuel consumption pattern in rural areas of Himachal Pradesh which indicated that fuel wood consumption by households $(95.2 \%)$ having very dominant share despite the fact that the other fuel option, like, kerosene (38.45\%), LPG (70\%) and crop residue $(94.5 \%)$ were also being used [10]. The fuelwood consumption constituted about $52 \%$ of the total energy consumption of the state [11]. About 2.7 hours per person per trip in the rural areas, were spent for the collection of fuel wood mainly during winter. The pattern of energy consumption in India is changing. In 2006-07, industry sector consumed $44 \%$ of commercial energy while residential and commercial sectors consumed $15 \%$ and transport $17 \%[12]$.

The carbon dioxide $\left(\mathrm{CO}_{2}\right)$ emissions of the Indian economy by producing sectors and due to household final consumption were analyzed. The analysis was based on an input - output (IO) table and Social Accounting Matrix (SAM) for the year $2003-04$ that distinguished 25 sectors and 10 household classes. Total emissions of the Indian economy in 2003-04 were estimated to be 1217 million tonne of $\mathrm{CO}_{2}$, of which $57 \%$ is due to the use of coal and lignite [13]. The per capita emissions turned out to be about 1.14 tons. The highest direct emissions were due to electricity sector followed by manufacturing, steel and road transportation. Final demands for construction and manufacturing sectors accounted for the highest emissions considering both direct and indirect emissions as the outputs from almost all the energy intensive sectors went into the production process of two sectors. In terms of life style differences across income classes, the urban top $10 \%$ accounted for emissions of $3416 \mathrm{~kg}$ per year while rural bottom $10 \%$ class accounted for only $141 \mathrm{~kg}$ per year. The $\mathrm{CO}_{2}$ emission embodied in the consumption basket of top $10 \%$ of the population in urban India is one-sixth of the per capita emission generated in the USA.

India currently emits approximately $4 \%$ of global GHG emissions. However, its per capita emissions are only one-quarter of the global average and less than one-tenth of those of most developed nations. India has committed to reducing the emissions intensity of its economy to $20 \%-$ $25 \%$ below 2005 levels by 2020 and that per capita GHG emissions will not exceed those of industrialized nations [14].

Carbon dioxide concentration in the atmosphere has been rising alarmingly in the post-industrial revolution era and the current level is about $379 \mathrm{ppm}$ (parts per million) compared to $280 \mathrm{ppm}$ earlier (pre-industrialization). The Planning Commission, Government of India, in the 12th Five-Year Plan of the country advocates low carbon growth, evident from the proposed actions to reduce India's emission intensity by $20-25 \%$ in 2020 as compared to emissions in 2005[15].

The National Action Plan on Climate Change (NAPCC), government of India, which was released in June 2008 with the aim of promoting development goals while addressing GHG mitigation and climate change adaptation. NAPCC suggests that up to $15 \%$ of India's energy could come from renewable sources by 2020 . The total power from renewable energy in the country as on March 2013 is 28951.82 MW. About 4.655 million biogas plants have been installed in the country as on March 2013 and the solar water heating systems with 6.98 million sqm of collector area have been installed in the country [16].

Energy system in mountainous regions is complex due to the wide variations in the availability and demand of energy resources. Mountain inhabitants are traditionally dependent on bio-energy resources such as fuel wood, agro and animal residues for meeting their energy requirements for heating, cooking, etc. However, depleting forest resources limit the availability of fuel wood while commercial sources such as LPG and kerosene fail to meet the domestic energy demands due to logistic and economic constraints. Hence, the inhabitants are forced to follow inefficient and ad hoc usage of juvenile forest trees (thus hindering regeneration), agro and animal residues, disregarding their alternative utilities.

In Himachal Pradesh the contribution of fuel wood as a source of energy is not limited to rural energy systems only, but urban areas too account for a share of fuel wood consumption which contributes to the disruption of rural energy supplies. The important conventional fuel in the state is electricity which is presently available in abundance in the state at subsidized rates.

The energy demand and supply varies with change in climatic and geographical conditions due to which the fuel consumption pattern also changes which needs to be studied. Lahaul \& Spiti district has an area of $13,833 \mathrm{Km}^{2}$ and is the largest district of Himachal Pradesh in size with total population of 31,528 . The altitude ranges from 3,350 meter to 5,856 meters in the district. The district adjoining to Tibet is one of the remote, tribal and snow bound area of the country. The average snowfall in the district is $1185.8 \mathrm{~cm}$. The space heating is a major requirement apart from cooking. 
Since the vegetation is quite low, the fuelwood is supplied from lower area of the state by the state government on subsidized rates and too in limited quantity. The kerosene is also supplied in limited quantity in the area to meet out the requirement of lighting during break down of electricity. The area remains cut off from the rest of the state during winters. The area experiences only two seasons e.i. winter and summer. The tribal people living in border and snow bound area faces problems of energy sources. The local wine prepared in almost every house particularly during winters requires additional source of energy. Keeping in view of above geographical, climatically and social scenario it is important to carry out a survey on energy consumption in households sector.

\section{Methodology}

Systematic methodology is the base of any scientific study as the precision; reliability and validity of scientific enquiry depend upon appropriate methodology. Multistage random sampling procedure was adopted for the selection of respondents from the study area as the sampling on contiguous basis may not be the best way to adopt. The Lahaul \& Spiti district of Himachal Pradesh was selected for the study as not much investigation for energy consumption pattern has been undertaken for this area. Both the blocks (Lahaul block and Spiti block) have been considered for the study (Fig. 1 and Fig. 2). In the first stage, list of panchayat falling in these blocks was prepared from concerned revenue offices. Around $25 \%$ of the total panchayats, aggregating to 8 panchayats were randomly selected. In the second stage, list of villages falling under the selected panchayats was prepared form the records of districts panchayat officers. $30 \%$ of the villages from the selected panchayats (aggregating to 48 villages) were selected for the study. In the final stage of sampling, a complete list of households was prepared in consultation with panchayat secretaries and village elders from the selected villages in the block and thereafter a representative sample of household from selected villages were considered for survey. In total 320 respondents were selected from the whole district for the survey purposes. Thereafter the farmers/respondents were classified on the basis of 3 categories, viz. Above Poverty Line (APL) or Below Poverty Line (BPL), land holding and income group.

The primary data were collected on well designed, pre-tested survey schedule (in local language) through personal interview method. Participatory techniques were also utilized for the collections of the relevant information on socio- economic variables like household income, land holding, different sources of fuel including fuel wood, kerosene, electricity, dung cakes, LPG and awareness about fuel saving devices in the study area. The secondary data such as map of the district, list of panchayats and villages were collected from offices of respective rural development blocks of state government. The list of households, landholding was collected from concerned department. The price of fuelwood, LPG, kerosene, electricity was obtained from different sources.

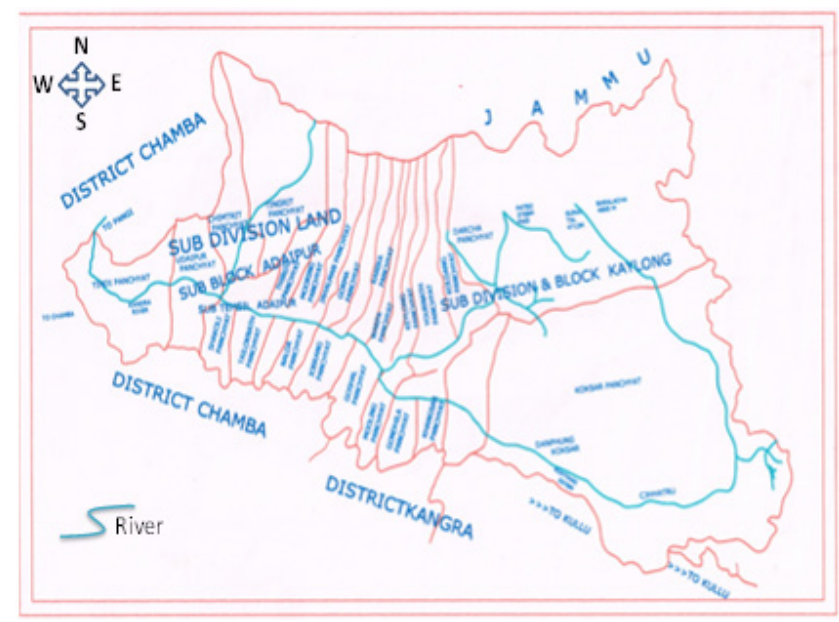

Figure 1. Map of Lahaul block

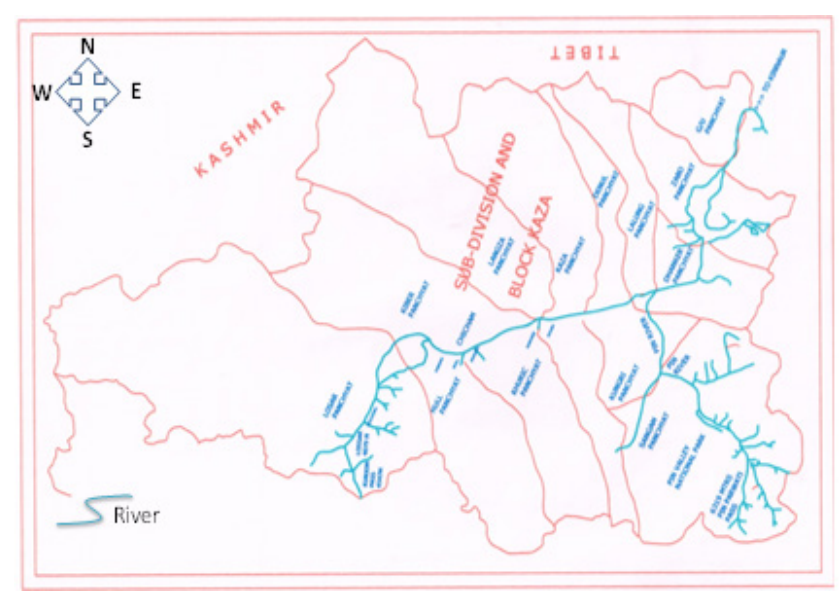

Figure 2. Map of Spiti block

\section{Results and Discussion}

The study indicated that the majority $(68.75 \%)$ of the respondent households belong to above poverty line (APL) category whereas a small $(31.25 \%)$ proportion belongs to BPL (Table 1.).

Income-wise distribution of sample households does not show any specific pattern. The majority $(31.56 \%)$ of households in the district fall under high income category i.e. earning more than Rs. 16,000 per month whereas the lowest (19.06\%) percentage of households belong to the Low middle income (Rs.4,000-8,000). Distribution of households as per the land holdings reveals that majority $(66.88 \%)$ of the households are marginal farmers, with land holdings less than one hectare and only $0.63 \%$ per cent had land holdings of more than 4 ha. The distribution of households according to family size suggested that a family of $\leq 4$ members is a 
common phenomenon in the study area. The majority of farmers were in this group of family size. The highest proportion of the families (55.94\%) was observed to have a family size of $\leq 4$ persons and only $9.69 \%$ of the families had 7-8 members. The distribution of households as per family size (\%) in Lahaul block is presented in Fig. 3 and distribution of households as per family size (\%) in Spiti block has been presented in Fig. 4 .

Table 1. Distribution pattern of households into different categories in district Lahaul and Spiti

\begin{tabular}{|c|c|c|}
\hline Particulars & Distribution (\%) & Total No. of respondents \\
\hline APL & 68.75 & 220 \\
\hline BPL & 31.25 & 100 \\
\hline TOTAL & 100.00 & 320 \\
\hline \multicolumn{3}{|c|}{ Monthly income (Rs.) } \\
\hline$<4000$ & 29.38 & 94 \\
\hline $4000-8000$ & 19.06 & 61 \\
\hline $8000-16000$ & 20.00 & 64 \\
\hline$>16000$ & 31.56 & 101 \\
\hline TOTAL & 100.00 & 320 \\
\hline \multicolumn{3}{|c|}{ Land holding (ha) } \\
\hline$<1$ & 66.88 & 214 \\
\hline $1-2$ & 25.31 & 81 \\
\hline $2-4$ & 7.19 & 23 \\
\hline$>4$ & 0.63 & 2 \\
\hline TOTAL & 100.00 & 320 \\
\hline \multicolumn{3}{|c|}{ Family size (No.) } \\
\hline$\leq 4$ & 55.94 & 179 \\
\hline $5-6$ & 34.38 & 110 \\
\hline $7-8$ & 9.69 & 31 \\
\hline$>8$ & 0.00 & 0 \\
\hline TOTAL & 100.00 & 320 \\
\hline
\end{tabular}

The study indicated that at district level APL families consume maximum fuel wood (56.14\%) and LPG (8.87\%), while BPL families dominate in consumption of fuels such as kerosene and cowdung (Table 2.) and (Fig. 5). The study revealed that fuelwood is the main source of energy for heating. The APL families consume (80.91\%) fuelwood for heating as compared to BPL families $(76.0 \%)$, followed by cowdung which is consumed more by BPL $(19.00 \%)$ than APL (16.36\%). The most households $(79.38 \%)$ consume fuelwood for heating followed by cowdung (17.19\%), kerosene $(2.19 \%)$ mainly for igniting the fuelwood and electricity $(1.25 \%)$ mainly by the government officers from outside of the district. The fuelwood consumption in the study area is high as compared to the fuelwood consumption of about $52 \%$ of the total energy consumption of the state [11].

The study indicated that electricity is a main source for lighting although kerosene is also used for lighting. The APL families $(84.09 \%)$ consume electricity for lighting as compared to BPL families $(78.00 \%)$ followed by kerosene which is consumed more by BPL (22\%) than APL (15.91\%). Income- wise analysis showed that electricity consumption increases with the increase in income whereas kerosene consumption decreases with increase in income of the household. This shows that as income increases the people are interested in electricity. This showed that as income increases the people get interested in electricity which is a cleaner energy source.

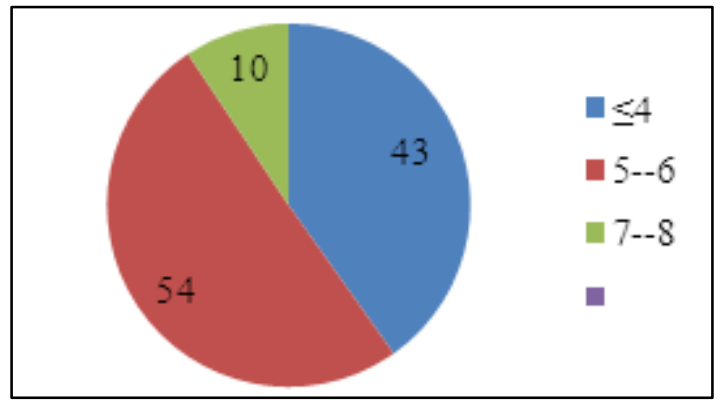

Figure 3. Distribution of households as per family size (\%) in Lahaul block

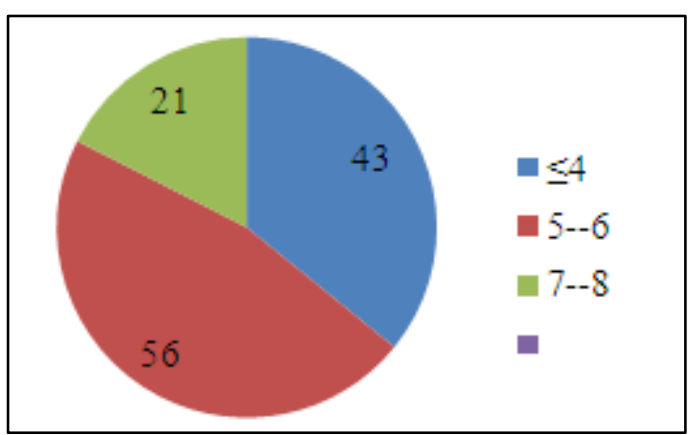

Figure 4. Distribution of households as per family size (\%) in Spiti block

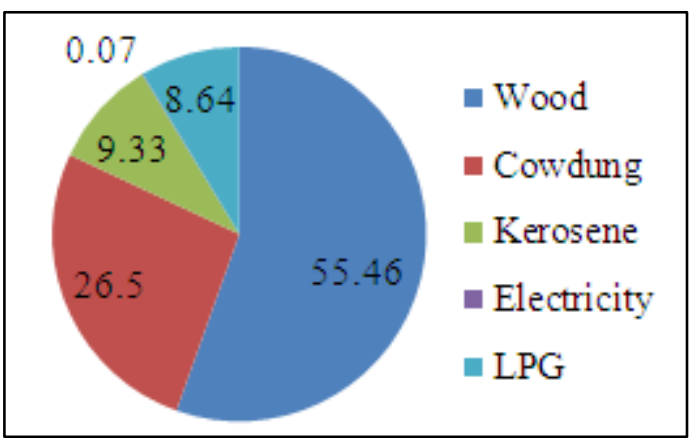

Figure 5. Cooking energy consumption (\%) in Lahaul and Spiti district

The study revealed that all the households consume LPG $(<5$ cylinders per season) mainly for cooking during winters (Table 3). The kerosene consumption (upto 1 liter per day) is done by $(89 \%)$ of households and consumption $>1$ lt/day by about $(11 \%)$ households. The fuelwood consumption of about $(48 \%)$ by the households is in the range of $6-10$ $\mathrm{kg} /$ day and that of the rest in the range $<5 \mathrm{~kg} /$ day in the district during winters. The cowdung consumption of about $(68 \%)$ households is in the range of $2-4 \mathrm{~kg} /$ day during winters and that of about (51\%) households is in the range of $<2 \mathrm{~kg} /$ day. This showed that during winters the consumption of fuelwood and cowdung increases. 
Table 2. Cooking energy consumption pattern in Lahaul and Spiti district (\%)

\begin{tabular}{|c|c|c|c|c|c|c|}
\hline \multirow[b]{2}{*}{ Particulars } & \multicolumn{6}{|c|}{ Energy source } \\
\hline & Fuelwood & Cowdung & Kerosene & Electricity & LPG & $\begin{array}{l}\text { Total no of } \\
\text { respondent }\end{array}$ \\
\hline APL & 56.14 & 25.87 & 9.05 & 0.06 & 8.87 & 220 \\
\hline BPL & 53.65 & 28.20 & 10.07 & 0.06 & 8.00 & 100 \\
\hline OVERALL & 55.46 & 26.50 & 9.33 & 0.07 & 8.64 & 320 \\
\hline \multicolumn{7}{|c|}{ Monthly income (Rs.) } \\
\hline$<4000$ & 54.06 & 27.01 & 5.42 & 0.05 & 4.95 & 94 \\
\hline $4000-8000$ & 57.90 & 24.31 & 9.61 & 0.07 & 8.11 & 61 \\
\hline $8000-16000$ & 53.67 & 27.25 & 8.98 & 0.05 & 10.03 & 64 \\
\hline$>16000$ & 55.91 & 26.72 & 8.85 & 0.07 & 8.44 & 101 \\
\hline OVERALL & 55.46 & 26.50 & 9.33 & 0.07 & 8.64 & 320 \\
\hline \multicolumn{7}{|c|}{ Land holding (ha) } \\
\hline$<1$ & 54.66 & 27.17 & 9.55 & 0.08 & 8.51 & 214 \\
\hline $1--2$ & 56.35 & 27.03 & 8.53 & 0.07 & 8.02 & 81 \\
\hline $2-4$ & 45.19 & 34.79 & 8.40 & 0.05 & 11.56 & 23 \\
\hline$>4$ & 28.19 & 14.09 & 7.98 & 0.03 & 8.32 & 2 \\
\hline OVERALL & 55.46 & 26.50 & 9.33 & 0.07 & 8.64 & 320 \\
\hline \multicolumn{7}{|c|}{ Family size (No.) } \\
\hline$\leq 4$ & 53.47 & 27.81 & 9.90 & 0.07 & 8.74 & 179 \\
\hline $5-6$ & 57.90 & 25.45 & 8.98 & 0.06 & 7.61 & 110 \\
\hline $7-8$ & 42.06 & 42.74 & 6.08 & 0.05 & 9.05 & 31 \\
\hline OVERALL & 55.46 & 26.50 & 9.33 & 0.07 & 8.64 & 320 \\
\hline
\end{tabular}

Table 3. Consumption pattern of fuel among different categories of household in Lahaul and Spiti district during winter season (\%)

\begin{tabular}{|c|c|c|c|c|c|c|c|c|c|c|c|c|}
\hline \multirow{3}{*}{ Particulars } & \multicolumn{12}{|c|}{ Energy source } \\
\hline & \multicolumn{3}{|c|}{ Fuelwood (kg/day) } & \multicolumn{2}{|c|}{$\begin{array}{l}\text { Kerosene } \\
\text { (litre/day) }\end{array}$} & \multicolumn{2}{|c|}{$\begin{array}{c}\text { LPG (No of } \\
\text { cylinder/season) }\end{array}$} & \multicolumn{3}{|c|}{ Cow dung (kg/day) } & \multicolumn{2}{|c|}{$\begin{array}{l}\text { Electricity } \\
\text { (Rs./month) }\end{array}$} \\
\hline & $\leq 5$ & $6--10$ & $>10$ & Up to1 & $>1$ & $\leq 5$ & $\leq 2$ & $3--4$ & $>4$ & $\leq 200$ & $200--250$ & $>250$ \\
\hline APL & 33.09 & 58.62 & 8.29 & 90.09 & 9.91 & 100.00 & 33.00 & 48.50 & 18.50 & 43.38 & 47.49 & 9.13 \\
\hline BPL & 67.12 & 32.03 & 0.84 & 88.66 & 11.34 & 100.00 & 27.56 & 60.20 & 12.24 & 48.51 & 46.53 & 4.95 \\
\hline OVERALL & 35.97 & 57.73 & 6.30 & 89.69 & 10.31 & 100.00 & 31.11 & 52.17 & 16.72 & 45.00 & 47.19 & 7.81 \\
\hline \multicolumn{13}{|c|}{ Monthly income (Rs.) } \\
\hline$<4000$ & 72.59 & 24.75 & 2.66 & 93.62 & 6.38 & 100.00 & 65.22 & 51.09 & 14.13 & 61.70 & 38.30 & - \\
\hline $4000-8000$ & 58.52 & 38.81 & 2.67 & 90.32 & 9.68 & 100.00 & 38.59 & 47.37 & 14.04 & 49.15 & 44.07 & 6.78 \\
\hline $8000-16000$ & 51.93 & 46.73 & 1.34 & 92.31 & 7.69 & 100.00 & 36.47 & 48.33 & 15.00 & 44.62 & 52.31 & 3.08 \\
\hline$>16000$ & 39.91 & 49.66 & 10.43 & 83.84 & 16.16 & 100.00 & 18.89 & 58.89 & 22.22 & 27.45 & 53.92 & 18.63 \\
\hline OVERALL & 35.97 & 57.73 & 6.30 & 89.69 & 10.31 & 100.00 & 31.11 & 52.17 & 16.72 & 45.00 & 47.19 & 7.81 \\
\hline \multicolumn{13}{|c|}{ Land holding (ha) } \\
\hline$<1$ & 48.88 & 46.05 & 5.07 & 92.52 & 7.48 & 100.00 & 32.34 & 54.23 & 13.43 & 49.53 & 45.33 & 5.14 \\
\hline $1-2$ & 47.73 & 46.22 & 6.06 & 85.37 & 14.63 & 100.00 & 28 & 45.33 & 26.67 & 39.51 & 48.15 & 12.35 \\
\hline $2-4$ & 35.48 & 56.91 & 7.60 & 73.91 & 26.09 & 100.00 & 61.91 & 52.38 & 14.29 & 26.09 & 60.87 & 13.04 \\
\hline$>4$ & - & 100.00 & - & 100.00 & - & 100.00 & - & 100.00 & - & - & 50.00 & 50.00 \\
\hline OVERALL & 35.97 & 57.73 & 6.30 & 89.41 & 10.59 & 100.00 & 31.11 & 52.17 & 16.72 & 45.00 & 47.19 & 7.81 \\
\hline \multicolumn{13}{|c|}{ Family size (No.) } \\
\hline$\leq 4$ & 47.19 & 51.00 & 1.81 & 91.71 & 8.29 & 100.00 & 31.75 & 52.38 & 15.87 & 49.26 & 45.81 & 4.93 \\
\hline $5-6$ & 49.87 & 43.06 & 7.07 & 88.35 & 11.65 & 100.00 & 31.91 & 50.00 & 18.09 & 38.38 & 49.49 & 12.12 \\
\hline $7-8$ & 30.49 & 26.82 & 42.69 & 79.17 & 20.83 & 100.00 & 18.75 & 62.50 & 18.75 & 23.53 & 58.82 & 17.65 \\
\hline OVERALL & 35.97 & 57.73 & 6.30 & 89.69 & 10.31 & 100.00 & 31.11 & 52.17 & 16.72 & 44.51 & 47.65 & 7.84 \\
\hline
\end{tabular}


Table 4. Consumption pattern of fuel among different categories of household in Lahaul and Spiti district (summer season)

\begin{tabular}{|c|c|c|c|c|c|c|c|c|}
\hline \multirow{3}{*}{ Particulars } & \multicolumn{8}{|c|}{ Energy source } \\
\hline & \multirow{2}{*}{$\begin{array}{c}\begin{array}{c}\text { Cow dung } \\
\text { (kg/day) }\end{array} \\
<2 \\
\end{array}$} & \multicolumn{3}{|c|}{ Electricity (Rs./month) } & \multirow{2}{*}{$\begin{array}{c}\begin{array}{c}\text { Kerosene } \\
\text { (litre/day) }\end{array} \\
\text { upto } 1 \\
\end{array}$} & \multirow{2}{*}{$\begin{array}{c}\begin{array}{c}\text { Fuelwood } \\
\text { (kg/day) }\end{array} \\
<5 \\
\end{array}$} & \multicolumn{2}{|c|}{$\begin{array}{c}\text { LPG (No. of } \\
\text { cylinder/season) }\end{array}$} \\
\hline & & $<200$ & $200-250$ & $>250$ & & & $<5$ & $5-10$ \\
\hline APL & 100.00 & 33.56 & 45.60 & 20.84 & 100.00 & 100.00 & 30.28 & 69.72 \\
\hline BPL & 100.00 & 58.35 & 40.30 & 1.35 & 100.00 & 100.00 & 67.24 & 32.76 \\
\hline OVERALL & 100.00 & 35.40 & 47.58 & 17.54 & 100.00 & 100.00 & 41.00 & 59.00 \\
\hline \multicolumn{9}{|c|}{ Monthly Income (Rs.) } \\
\hline$<4000$ & 100.00 & 56.61 & 41.13 & 2.26 & 100.00 & 100.00 & 73.72 & 26.28 \\
\hline $4000-8000$ & 100.00 & 45.80 & 50.27 & 3.93 & 100.00 & 100.00 & 36.11 & 63.89 \\
\hline $8000-16000$ & 100.00 & 39.92 & 51.65 & 8.43 & 100.00 & 100.00 & 45.24 & 54.76 \\
\hline$>16000$ & 100.00 & 18.24 & 56.64 & 25.12 & 100.00 & 100.00 & 13.85 & 86.15 \\
\hline OVERALL & 100.00 & 35.40 & 47.58 & 17.54 & 100.00 & 100.00 & 41.00 & 59.00 \\
\hline \multicolumn{9}{|c|}{ Land holding (ha) } \\
\hline$<1$ & 100.00 & 39.66 & 50.28 & 10.06 & 100.00 & 100.00 & 50.00 & 50.00 \\
\hline $1--2$ & 100.00 & 20.60 & 61.07 & 18.33 & 100.00 & 100.00 & 26.67 & 73.33 \\
\hline $2--4$ & 100.00 & 11.34 & 60.78 & 27.88 & 100.00 & 100.00 & 23.08 & 76.92 \\
\hline OVERALL & 100.00 & 35.40 & 46.58 & 17.54 & 100.00 & 100.00 & 41.00 & 59.00 \\
\hline \multicolumn{9}{|c|}{ Family size (No.) } \\
\hline$\leq 4$ & 100.00 & 48.33 & 50.04 & 1.62 & 100.00 & 100.00 & 44.68 & 55.32 \\
\hline $5-6$ & 100.00 & 33.94 & 49.99 & 16.07 & 100.00 & 100.00 & 37.50 & 62.50 \\
\hline $7-8$ & 100.00 & 13.56 & 57.86 & 28.58 & 100.00 & 100.00 & 29.03 & 70.97 \\
\hline OVERALL & 100.00 & 35.40 & 47.58 & 17.54 & 100.00 & 100.00 & 41.00 & 59.00 \\
\hline
\end{tabular}

The study indicated that during summers the fuelwood consumption $(<5 \mathrm{~kg} /$ day $)$ and kerosene consumption up to one liter/day and cowdung consumption $<2 \mathrm{~kg}$ /day is $100 \%$ irrespective of household category in the district, whereas about $59 \%$ of households were consuming LPG in the range of 5-10 cylinders (Table 4). This revealed that during summers (April to September) the consumption of fuelwood and cowdung decreases and consumption of LPG increases. This is also because of the living life style of the people in the area as family members and relatives in winters generally sit together in a house.

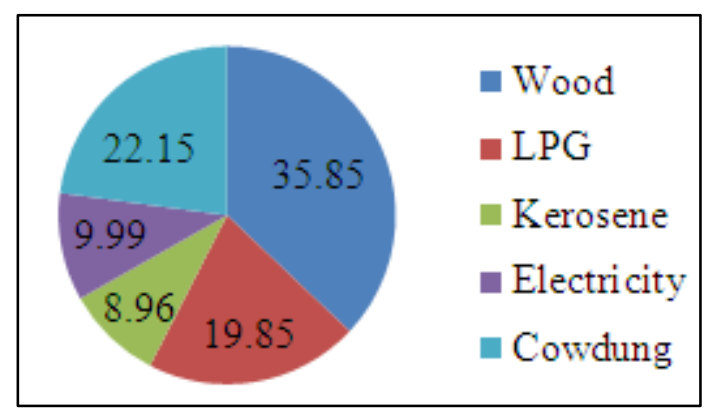

Figure 6. Preference of fuel for cooking (\%) in Lahaul and Spiti district

The area remain short of electricity supply for the most of the time and people are forced to use the traditional lamp with (kerosene fuel) to light up their rooms and houses. However, in the response for the preference of fuel for lighting, people of tribal and remote area place electricity as a first choice with almost $(90.63 \%)$ of the respondent showing preference for electricity (Table 5) and (Fig. 6). The study indicated that at the district level average $\mathrm{CO}_{2}$ emission of 4.94 tonnes is from fuelwood, 2.28 tonnes from kerosene and 0.32 tonnes from LPG (Table 6).

The study revealed that mainly the fossil fuels are being used to meet out the energy requirement of the tribal people has degraded the local environment. The increase in temperature due to burning of fossil fuels has resulted in one side the growth in agriculture but on the other side deserted the local fragile system. The people which are facing extreme climatic conditions has to face health problems particularly women and children due to use of conventional energy sources. The energy systems like metal cookstoves and kerosene lamps are inefficient and consume more fuel and creating environmental problem. Although the people in the area are provided with reservation in the government institutions still they have financial crunch to meet out their energy needs.

This necessitated the initiative by the government to provide fuelwood on subsidised rates, kerosene and solar energy based systems to meet out their energy requirements. Now the government of India has withdrawn the subsidy on solar energy systems from the current financial year, it will become difficult for the state government to carry out the solar energy projects on subsidised rates. This will create energy crises in the snow bound area in the coming years. 
Table 5. Preference of fuel for cooking (\%) in Lahaul and Spiti district

\begin{tabular}{|c|c|c|c|c|c|c|}
\hline Particulars & Wood & LPG & Kerosene & Electricity & Cowdung & $\begin{array}{l}\text { Total No. of } \\
\text { respondents }\end{array}$ \\
\hline APL & 34.21 & 21.93 & 12.28 & 9.65 & 21.93 & 220 \\
\hline BPL & 40.28 & 14.22 & 33.18 & 10.90 & 22.75 & 100 \\
\hline OVERALL & 35.85 & 19.85 & 8.96 & 9.99 & 22.15 & 320 \\
\hline \multicolumn{7}{|c|}{ Monthly income (Rs.) } \\
\hline$<4000$ & 51.15 & 9.77 & 40.23 & 7.47 & 19.54 & 94 \\
\hline $4000-8000$ & 35.22 & 22.01 & 44.03 & 10.69 & 21.38 & 61 \\
\hline $8000-16000$ & 16.52 & 12.91 & 21.02 & 6.91 & 13.21 & 64 \\
\hline$>16000$ & 30.53 & 22.90 & 26.72 & 9.54 & 23.28 & 101 \\
\hline OVERALL & 35.85 & 19.85 & 8.96 & 9.99 & 22.15 & 320 \\
\hline \multicolumn{7}{|c|}{ Land holding (ha) } \\
\hline$<1$ & 41.42 & 17.81 & 15.02 & 8.15 & 20.39 & 214 \\
\hline $1--2$ & 33.33 & 25.71 & 33.33 & 10.95 & 20.48 & 81 \\
\hline $2-4$ & 2.22 & 2.51 & 10.36 & 2.37 & 4.73 & 23 \\
\hline$>4$ & 22.22 & 11.11 & 22.22 & 11.11 & 33.33 & 2 \\
\hline OVERALL & 35.85 & 19.85 & 8.96 & 9.99 & 22.15 & 320 \\
\hline \multicolumn{7}{|c|}{ Family size (No.) } \\
\hline$\leq 4$ & 42.03 & 18.99 & 17.72 & 8.61 & 19.49 & 179 \\
\hline $5-6$ & 31.65 & 23.74 & 25.18 & 9.71 & 22.30 & 110 \\
\hline $7-8$ & 3.86 & 2.08 & 10.40 & 2.53 & 5.05 & 31 \\
\hline OVERALL & 35.85 & 19.85 & 8.96 & 9.99 & 22.15 & 320 \\
\hline
\end{tabular}

Table 6. Annual $\mathrm{CO}_{2}$ emissions (tonne) in Lahaul and Spiti district

\begin{tabular}{|c|c|c|c|c|}
\hline Particulars & Fuelwood & Kerosene & LPG & Total No of respondents \\
\hline APL & 5.24 & 2.31 & 0.33 & 220 \\
\hline BPL & 4.29 & 2.20 & 0.31 & 100 \\
\hline OVERALL & 4.94 & 2.28 & 0.32 & 320 \\
\hline \multicolumn{4}{|c|}{ Monthly income (in Rs.) } & \\
\hline$<4000$ & 4.37 & 2.18 & 0.29 & 94 \\
\hline $4000-8000$ & 5.22 & 2.37 & 0.34 & 61 \\
\hline $8000-16000$ & 4.98 & 2.26 & 0.31 & 64 \\
\hline$>16000$ & 5.28 & 2.31 & 0.34 & 101 \\
\hline OVERALL & 4.94 & 2.28 & 0.32 & 320 \\
\hline \multicolumn{4}{|c|}{ Land holding (ha) } & \\
\hline$<1$ & 4.65 & 2.26 & 0.31 & 214 \\
\hline $1-2$ & 5.19 & 2.17 & 0.34 & 81 \\
\hline $2--4$ & 6.71 & 2.80 & 0.37 & 23 \\
\hline$>4$ & 5.74 & 2.12 & 0.22 & 2 \\
\hline OVERALL & 4.95 & 2.28 & 0.32 & 320 \\
\hline \multicolumn{4}{|c|}{ Family size (No.) } & \\
\hline$\leq 4$ & 4.71 & 2.12 & 0.25 & 179 \\
\hline $5-6$ & 5.39 & 2.41 & 0.38 & 110 \\
\hline $7-8$ & 4.61 & 2.61 & 0.43 & 31 \\
\hline OVERALL & 4.95 & 2.28 & 0.32 & 320 \\
\hline
\end{tabular}




\section{Conclusions}

The annual fuel wood consumption of the district worked out to be 905.2 tonnes, all of which is being supplied by government on subsidized rates. The annual kerosene consumption of the district was 0.24 million litres. The annual LPG consumption of the district was 33.0 tonnes for cooking during summers. The $\mathrm{Co}_{2}$ emission from burning of conventional energy was estimated to be 2445.5 tonnes per year in the district. It was observed that people were not aware of the use of Renewable Energy Technologies (RETs) which could reduce the burden on conventional fuels as well as reduce the GHG emissions. Only solar photovoltaic lights were found functional in the study area. Keeping in view of topographic, climatic and social aspects of the area the remedial measures are urgently required. The RETs were initially supplied on subsidized rates, but their quality could not be ensured and no technical facilities like repair, maintenance was available. Therefore, it is suggested that quality maintenance may be ensured. After gradual withdrawal of subsidies, the RETs were bound to be beyond the reach of common man in the area. Therefore, incentives in the form of rebate in house tax or in the cost of devices may be given to the persons adopting RETs to encourage people to use them. The state should carry out extensive information, education and communication (IEC) awareness activities at grass root level and encourage people to adopt RETs. The state government should make it mandatory to incorporate solar passive features, solar water heater in all government buildings.

\section{Acknowledgements}

The facilities provided by the department of Environmental Science, Dr Y S Parmar University of Horticulture \& Forestry, Nauni to carry out this study are highly appreciated.

\section{REFERENCES}

[1] R. Sood, R K, Aggarwal, P. K. Mahajan, S. K. Bhardwaj and Sharma S. Estimation of domestic energy consumption and carbon emission in Mid Himalayan Region of Himachal Pradesh, India,Journal of Agriculture and Environmental sci loopet exerts 4nces, 3(1):141-147, 2014.
[2] B. Sinha and I. Biswas. Rural energy security in India: reality checks, India, Science and Technology: S\&T for Rural India and Inclusive Growth, New Delhi, 2008.

[3] R. Revelle. Energy use in rural India, Science, 192: 969-974, 1976.

[4] A. K. N. Reddy and K. K. Prashad. Technological alternatives and the Indian energy crisis, Economic and Political weekly,12:1465-150, 1977.

[5] R. C.Maheshwari, P. K. Srivastava and C. P. Bhora. Energy consumption and resource assessment of Islamabad in the Bhopal district, Bhopal: Central Institute of Agricultural Engineering, 1981.

[6] B. S. K. Sarma. .Forests for fuel, Indian Forester, 107(12):808-812, 1981.

[7] N. H. Ravindernath and H. N. Chanakya. Biomass based energy system for a South Indian village, Biomass, 9: 215-233, 1986.

[8] A. S. Guleria. Energy consumption pattern in Bharmaur Block of Chamba District of Himachal Pradesh. Report, Department of Economics, H.P.U., Shimla, 1987.

[9] L. R. Sharma, Ramesh Chand and, J. P. Bhatti.An analysis of farmers on forest for fuel wood, fodder and timber in Himachal Pradesh, Agricultural situation in India, 43(5):359-363, 1989.

[10] R. K. Aggarwal. Fuel consumption pattern for policy intervention and integrated planning in rural areas, SESI journal,19(1\&2):82-91, 2009.

[11] R. K. Aggarwal and S. S. Chandel. Emerging energy scenario in Western Himalayan state of Himachal Pradesh, Energy Policy, 38: 2545-2551, 2010.

[12] Tata Energy and Resources Institute. Teri Energy Data Directory and Yearbook, Chapter on Indian Energy Sector: an Overview, TERI, New Delhi, India, 2010.

[13] J.Parikh, M.Panda, A. Ganesh and Vinay. $\mathrm{CO}_{2}$ emissions structure of Indian economy, Energy, 30:1-7, 2009.

[14] Renewable Energy. Ministry of New and Renewable Energy, GOI, New Delhi, 2010.

[15] T. V.Ramachandra, Gautham Krishnadas, Bharath Setturu, Uttam Kumar. Regional Bio- energy Planning for Sustainability in Himachal Pradesh, India, Journal of Energy, Environment \& Carbon Credits, Volume 2, Issue 1: 13-49, 2012.

[16] Renewable Energy. Ministry of New and Renewable Energy, GOI, New Delhi, 2013. 